\title{
Challenges in Speaking Classrooms among Non-English Majors
}

\section{Ngoc Boi Trinh, Duy Thuy Thi Pham ${ }^{+}$}

\section{Article history}

Received: 08 April 2021

Accepted: 25 May 2021

Published: 30 June 2021

\section{Keywords \\ Non-English majors, psychological difficulties, linguistic difficulties, topical knowledge, inappropriate vocabulary}

\author{
Tra Vinh University, Vietnam \\ ${ }^{+}$Corresponding author •Email: thuyduy@tvu.edu.vn
}

\begin{abstract}
As a great challenge to most English learners, speaking skills have aroused the interest of numerous researchers in many countries where English is taught as a foreign language. This study aimed to investigate some difficulties that students faced in speaking classrooms. A group of 57 participants at Tra Vinh university was selected to complete the questionnaires to find out students' speaking problems from psychological and linguistic perspectives and 12 of them participated in the face-to face interviews. The results from the questionnaire revealed that non-English majors encountered more linguistic difficulties than psychological ones. Also, students' psychological problems identified includes: pressure to perform well, being overpowered by more competent students, fear of making mistakes in front of the class and fear of criticism or losing face. The linguistic difficulties are lacking vocabulary and topical knowledge, being uncapable of arranging ideas logically, insufficient sentence formation skills and inappropriate vocabulary. The findings from the interview also showed that learners encountered more linguistic difficulties. Based on the findings above, some possible solutions are suggested to assist students in improving their speaking skills when acquiring English.
\end{abstract}

\section{INTRODUCTION}

To study English effectively, learners need to master the four language skills: listening, speaking, reading and writing. Among them, listening and speaking seem to be more difficult to English learners from both linguistic and psychological perspectives. Consequently, some teachers tend to focus more on reading and writing skills instead of listening and speaking skills. According to Alam \& Uddin (2013), teachers usually employ their traditional teaching methods which emphasize on reading and writing while the productive skill of speaking is treated as trivial. In addition, Hodson (2006, as cited in Alam \& Uddin, 2013) claimed that the explicit teaching of speaking and listening has been neglected. As a result, students spend long hours learning grammar and vocabulary yet insufficient time for listening and speaking. In fact, some researchers such as Al Hosni (2014), Nguyen \& Tran (2015) and Riyaz \& Mullick (2016) proved that speaking is hard for most students because it requires learners to have good psychological and linguistic skills. Ur (2000) also suggested that learners encountered some problems in learning speaking skills relating to the fear of making mistakes, losing face, mother tongue use and poor ideas.

At Tra Vinh university, the majority of non-English majors have difficulties with listening and speaking skills. In this current study, learners at Tra Vinh University were investigated to identify what linguistic and psychological obstacles they encounter in learning speaking skills.

Research questions:

1. What linguistic obstacles do non-English majors face when learning speaking skills?

2. What psychological obstacles do non-English majors face when learning speaking skills?

\section{LITERATURE REVIEW}

\subsection{The importance of Speaking skills}

Speaking is considered one of the most important skills in both first and second language which is active, productive and requires more attention because speaking shows people's thinking and personalities (Nunan, 1991). 
Richards \& Renandya (2002) also stated that developing proficiency in speaking is the key purpose of a large number of language learners thanks to the various useful functions of speaking like describing things, complaining about people's behavior, making polite requests, etc.

Moreover, Fauziati (2010) indicated that the aim of learning speaking is to communicate effectively in different situations. Likewise, speaking is considered the basic skill in learning a language because it is developed from childhood together with listening skill (Tarigan, 1990, as cited in Riyaz and Mullick, 2016). Therefore, it is essential for learners to master the speaking skill to acquire a language.

However, increasing speaking proficiency demands learners' efforts and time to practice. In fact, learners' speaking can be significantly enhanced providing that they have more opportunities to expose to the target language as well as the cultures of the target language speakers (Riyaz and Mullick, 2016).

Hosni (2014) claimed that the learning process is more meaningful if learners can use accurately what they know about the language to show their thoughts or emotions in communicative interaction.

\subsection{Students' obstacles in learning speaking skills}

Learning English speaking is significantly challenging to a majority of Vietnamese learners due to significant differences between the two language systems. Their speaking difficulties have been clearly indicated by many scholars.

Ur (2000) classified leaners' speaking difficulties into four main categories which are inhibition, lack of ideas, low participation and habit of using mother tongue. Inhibition is a psychological factor that prevents learners from making speech. They are frequently afraid of the speaking power of others, making mistakes in front of their classmates or criticism and losing face while speaking.

Many other researchers also shared the same viewpoints that learners can have stressful and nervous feelings when they are asked to perform the speaking tasks. In addition, most learners sometimes do not have ideas about unfamiliar or uninteresting speaking topic assigned. Silence or low participation is the preferred way that learners choose when they are uncertain whether what they are going to say is correct. Learners usually prefer to use their first language in generating their ideas and then translate what they think into the target language (Pathan, Aldersi \& Alsout, 2014; Keong, Ali \& Hameed, 2015).

Some researchers believe that psychological factors such as confidence, motivation, and anxiety also have direct impacts on learners' speaking performance (Tobias \& Everson, 1997; Amini, Mojallal, Karimpour \& Alizadeh 2014).

Othman \& Shuqair (2013) believed that when confident language learners are eager, more enthusiastic, willing to participate in speaking activities, they will obtain more success in learning speaking. Meanwhile, learners who are too shy or under pressure of English speaking skill frequently avoid expressing what they are thinking in English. Another noticeable difficulty is unpleasant learning environment which may make learners uncomfortable to join the speaking activities. Creating stimulating speaking environment provides learners more opportunities to promote their motivation in speaking. Therefore, good psychological state allows learners to use their verbal language more fluently.

\subsection{Previous studies}

Al Hosni (2014) conducted the research on "Speaking difficulties encountered by young EFL learners". The purposes of the study were to find out the main speaking-related difficulties encountered by grade 5 students in basic education schools in Oman and the factors that contribute to the existence of these challenges. The study proved that grade 5 students faced both linguistic and psychological difficulties. Students couldn't speak in English because they lacked the necessary vocabulary items, grammatical structures and sentence formation skills. Also, they were afraid of making mistakes.

Nguyen \& Tran (2015) carried out a study on "Factors affecting students' speaking performance at Le Thanh Hien high school". This study aimed at exploring the speaking problems of the students at Le Thanh Hien high school and the factors affecting their speaking performance. The participants included two hundred and three grade 11 students and ten teachers of English. The results from the questionnaires and classroom observation indicated that students faced various problems such as speaking English very little or not at all, not being able to think of anything to say, using Vietnamese instead of English when discussing in groups or in pairs, having low participation, being fearful of criticism or losing face, having a habit of translating the information in the textbooks into Vietnamese before speaking and looking at their textbooks when speaking. From the findings above, the authors proposed some possible solutions to both teachers and students to improve teaching and learning speaking skills.

Riyaz \& Mullick (2016) conducted a study on "Problems in learning English speaking skill: A study of higher secondary students in Srinagar, India". The study focused on the difficulties encountered by learners at higher secondary level. The sample consisted of 160 respondents taken from various higher institutes of Srinagar city. The 
results showed that learners' overall performance in speaking skills was very low. They didn't have much exposure to English language use inside and outside the classroom. Also, students' lack of vocabulary, poor grammar and pronunciation and teachers' domination in the class hindered their progress in speaking.

All the three previous studies above present linguistic and psychological difficulties learners encountered when learning speaking skills. In this study, the authors also investigated what linguistic and psychological difficulties that the participants faced. Besides, we designed 2 open-ended questions to interview them to find out if they had additional linguistic or psychological problems they had in order to propose some suggested recommendations for both teachers and students to tackle their issues.

\section{MATERIALS AND METHODS}

\subsection{Research design}

In order to investigate non- English majors' obstacles in learning speaking skills, the combined methods were employed in this study to analyze the qualitative and quantitative data from the interview and the questionnaire.

\subsection{Participants}

The participants involved in the current study are 57 non-English majors at Tra Vinh university who have completed general English 1 and 2 courses. In the curriculum for training non- English majors at Tra Vinh University, students are required to learn general English courses from level 1 to level 4. The main course books are KET OBJECTIVE (for level 1) and PET OBJECTIVE (from level 2 to level 4) with integrated skills. Therefore, all four English skills of the students are assessed after finishing each level. There are two reasons for choosing these participants to complete the questionnaire and participate in the interview. First, during the process of teaching general English subjects to non-English majors, the authors have found out that the majority of first and second year non-English majors encounter certain challenges in speaking English. Secondly, many students receive bad marks in listening and speaking skills.

\subsection{Research instruments}

To answer the research questions of the current study, the researcher employed a questionnaire and an interview. The questionnaire focused on the participants' linguistic and psychological difficulties which were fully developed through the theoretical background and previous studies. All the items were designed by using a five-point Likert scale, ranging from strongly disagree to strongly agree. The questionnaire survey was adapted from Al Hosni (2014) and Nguyen \& Tran (2015) who mentioned both linguistic and psychological aspects in their questionnaires. The interview included two open-ended questions on whether the students had more difficulties with linguistic or psychological aspects and what other problems related to linguistic and psychological factors they encountered. The 2 open-ended questions in the interview were designed by the authors.

\subsection{Procedure}

First, the questionnaire was designed and piloted to check if it was clear enough to respondents. The participants involved in the pilot were 10 students who studied general English. The data collected from the questionnaire was analyzed by using the software SPSS version 25 (Statistic Package for the Social Sciences).

Regarding the face-to-face interview, we asked 12 out of 57 participants to find out if they had more linguistic problems or psychological ones and what other problem related to linguistic or psychological factors they usually encountered.

\section{RESULTS AND DISCUSSION}

\subsection{Results from the questionnaire}

The reliability of the questionnaire

Table 1. Reliability of the questionnaire

\begin{tabular}{cc}
\hline Cronbach's Alpha & N of Items \\
\hline .739 & 18 \\
\hline
\end{tabular}

The questionnaires were fully completed by a group of 57 students. All the data collected from the questionnaires were computed to check the frequency and the internal reliability coefficient. The result in table 1 shows that the questionnaire employed in this study was reliable with significantly high Cronbach Alpha's coefficient of .74 for 18 items in total. Key findings of the current research are discussed in depth in the following sections.

Linguistic difficulties

Table 2. Descriptive statistics of Linguistic difficulties

\begin{tabular}{lrr}
\hline Linguistic difficulties & Mean & Std. Deviation \\
\hline Uninteresting topics & 2.79 & 1.04 \\
\hline
\end{tabular}




\begin{tabular}{lcr}
\hline Habit of using the mother tongue & 3.98 & .94 \\
\hline Lack of sentence formation skills & 4.14 & .74 \\
\hline Lack of topical knowledge & 4.18 & .66 \\
\hline Lack of vocabulary & 4.61 & .56 \\
\hline Using inappropriate vocabulary & 4.02 & .67 \\
\hline Inaccurate pronunciation & 3.86 & .91 \\
\hline Being corrected mistakes while speaking & 2.53 & 1.04 \\
\hline Not being able to arrange ideas logically & 4.16 & .68 \\
\hline Being unable to listen well & 3.79 & .88 \\
\hline Overall mean & 3.81 & .36 \\
\hline
\end{tabular}

First, the descriptive statistic test shown in Table 2 reveals the overall mean score of linguistic factors is rather high $(\mathrm{M}=3.81, \mathrm{SD}=0.36)$. This proves that the participants encounter quite numerous difficulties in linguistic aspects in speaking English. In particular, the data indicates that most participants believe that they lack vocabulary with the highest mean score $(\mathrm{M}=4.61, \mathrm{SD}=0.56)$. There is a convincing reason that they may have some problems with their vocabulary retention after taking much time to learn them by heart. At the time of learning new words, they can remember and use them in speaking. Then, without the regular speaking practice, most of the words escapes their memory. The next difficulty is lacking topical knowledge $(\mathrm{M}=4.18, \mathrm{SD}=0.66)$. This can be explained by the fact that participants seldom read newspapers or watch TV on different topics to accumulate their knowledge. Also, they lack real life experience. Moreover, not being able to arrange ideas logically and insufficient sentence formation skills also prevent students from speaking in English ( $\mathrm{M}=4.16, \mathrm{SD}=0.68 ; \mathrm{M}=4.14, \mathrm{SD}=0.74$ respectively). The majority of the learners think that they can't speak in a logical way and this may confuse others. In addition, they believe that grammatical knowledge makes a remarkable contribution to the success of speaking; however, there are many different structures and various ways of forming phrases or sentences.

Psychological difficulties

Table 3. Descriptive statistics of psychological difficulties

\begin{tabular}{lrr}
\hline \multicolumn{1}{c}{ Psychological difficulties } & Mean & Std. Deviation \\
\hline Pressure to perform well & 4.02 & .94 \\
\hline Fear of making mistakes in front of classmates & 3.33 & 1.00 \\
\hline Fear of criticism or losing face & 3.09 & 1.07 \\
\hline Being overpowered by better students & 3.58 & 1.05 \\
\hline Unpleasant atmosphere & 2.94 & 1.12 \\
\hline Having no intrinsic motivation & 2.28 & 1.18 \\
\hline Lack of motivation to speak & 2.49 & .63 \\
\hline Lack of listeners' support & 2.42 & .57 \\
\hline Overall mean & 3.05 & .49 \\
\hline
\end{tabular}

The Descriptive Statistics shown in Table 3 presents the total mean score of eight items of psychological difficulties of the participants in English speaking is $(M=3.05, S D=0.49)$. It can be concluded that the participants have difficulties with psychology in English speaking classrooms with the average level.

Of all the problems, participants are mainly under the pressure of having successful speaking performance $(\mathrm{M}=$ $4.02, \mathrm{SD}=0.94)$. They show a highly positive perception towards what they are going to talk. Some students believe that they are overpowered by better students $(\mathrm{M}=3.58, \mathrm{SD}=1.05)$. Clearly, weaker students tend to keep silent when they have to work in pairs or groups with more competent students.

Moreover, they also fear of making mistakes in front of the class and criticism or losing face with $(\mathrm{M}=3.33)$ for the former and $(\mathrm{M}=3.09)$ for the latter. The results above prove that if they don't get support or motivation from teachers and friends, they will lose the confidence to express their ideas.

The impact of psychological and linguistic factors in comparison

Table 4. The impact of psychological and linguistic factors in comparison

\begin{tabular}{cccc}
\hline & \multicolumn{1}{c}{ Difficulties } & Mean & \multicolumn{2}{c}{ Std. Deviation } \\
\hline \multirow{2}{*}{ Mean } & linguistic difficulties & 3.81 & .36 \\
\cline { 2 - 5 } & psychological difficulties & 3.05 & .49 \\
\hline
\end{tabular}


Regarding psychological aspects, the participants were influenced most by the following issues: pressure to perform well, being overpowered by better students, fear of making mistakes in front of the class and fear of criticism or losing face. Interestingly, Nguyen \& Tran (2015) also claimed that a significant number of students stated that they were fearful of criticism or losing face. According to Al Hosni (2014), the learners in his study were also afraid of making mistakes when communicating in English.

Based on the results of the study, we propose some recommendations to help non-English majors improve their speaking skills. First, teachers should design various activities which are meaningful, familiar, and authentic in the speaking classes such as role-play, discussing, debating, describing pictures, watching English video clips or films, playing enjoyable speaking games and oral presentation. Secondly, to achieve the goal of communication, students should be encouraged to take part in speaking activities in pairs or groups because they feel more comfortable and natural when talking with their classmates. Thirdly, teachers should focus on the frequently used grammatical structures for each topic to limit making mistakes. Moreover, guiding students to pronounce new words is also important so that they are able to identify the stress and linking sounds. Finally, some speaking activities outside the class such as English speaking club, participating in field trips, talking with foreign volunteer teachers are also essential for students to experience the use of English in real life.

\section{REFERENCES}

Al Hosni, S. (2014). Speaking difficulties encountered by young EFL learners. International Journal on Studies in English Language and Literature (IJSELL), 2(6), 22-30.

Abdullah, K. I., \& Abdul Rahman, N. L. (2010). A study on second language speaking anxiety among UTM students. A Study on Second Language Speaking Anxiety among UTM Students, 1-6.

Alam, Q., \& Bashiruddin, A. (2013). Improving English oral communication skills of Pakistani public school's students. International journal of English language teaching, 1(2), 17-36.

Amini, N. S., Mojallal, C., Karimpour, S. \& Alizadeh, S. (2014). Anxiety and Speaking English as a Second Language among Iranian English Major Students of Payame Noor University. J. Educ. Manage. Stud., 4(4), 872-876.

Fauziati, E. (2010). Teaching English as a foreign language (TEFL). https://doi.org/10.4324/9780203432860-79

Keong, Y. C, Ali, A. I. \&Hameed, F. W. (2015). Speaking competence if Iraqi EFL undergraduates of Garmiyan university. International Journal of Education and Research, 3(5), 157-170.

Gan, Z. (2012). Understanding L2 speaking problems: Implications for ESL curriculum development in a teacher training institution in Hong Kong. Australian Journal of Teacher Education, 37(1), 3.

Nunan, D. (1991). Language Teaching Methodology. A Textbookfor Teachers. New York, Pentice Hall Intermediate (UK) Ltd.

Nguyen, H. T. \& Tran, N. M. (2015). Factors affecting students' speaking performance at Le Thanh Hien high school. Asian Journal of Educational Research, 3(2), 8-23.

Othman, F. H. M. A. \& Shuquair, K. M. (2013). The impact of motivation on English language learning in the Gulf States. International Journal of Higher Education, 2(4), 123-130.

Pathan, M., Aldersi, Z. \& Alsout, E. (2014). Speaking in their Language: An Overview of Major Difficulties Faced by the Libyan EFL Learners in Speaking Skill. International Journal of English Language \& Translation Studies, 2(3), 96-105.

Richards, J. C., \& Renandya, W. A. (Eds.). (2002). Methodology in language teaching. Cambridge: Cambridge University Press.

Riyaz, H. \& Mullick, A. P. (2016). Problems in learning English Speaking Skill: A study of Higher Secondary Students in Srinagar, India. International Journal of Interdisciplinary and Multidisciplinary Studies (IJIMS), 3(2), 59-69.

Tobias, S., \& Everson, H. T. (1997). Studying relationship between affective and meta cognitive variables. Anxiety, Stress, and Coping, 10, 5981.

Ur, P. (2000). A course in Language Teaching: Practice and Theory. Cambridge: Cambridge University Press. 